\title{
AQUATIC RESEARCH
}
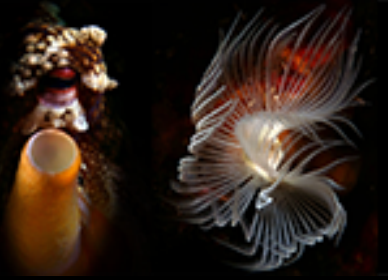

\section{Determination of serotypic differences of Lactococcus garvieae isolates obtained from rainbow trout farms}

\author{
Şükrü Önalan ${ }^{1}$, Muhammet Arabac1 ${ }^{1}$, Haşmet Çağırgan²® \\ Cite this article as: \\ Önalan, Ş., Arabacı, M., Çağırgan, H. (2020). Determination of serotypic differences of Lactococcus garvieae isolates obtained from trout farms. Aquatic \\ Research, 3(3), 135-143. https://doi.org/10.3153/AR20012
}

${ }^{1}$ Van Yuzuncu Yil University, Fisheries Faculty, Van, Turkey

${ }^{2}$ Ege University, Fisheries Faculty, İzmir, Turkey

ORCID IDs of the author(s):

Ş.Ö. 0000-0003-0058-5232

M.A. 0000-0002-2462-644

H.Ç. 0000-0003-3038-6154

Submitted: 17.03 .2020

Revision requested: 20.04 .2020

Last revision received: 28.04 .2020

Accepted: 30.04 .2020

Published online: 07.05 .2020

Correspondence: Şükrü ÖNALAN

E-mail: sukruonalan@yyu.edu.tr

\begin{abstract}
This study aimed to determine the serotypic differences between Lactococcus garvieae strains isolated from rainbow trout obtained from different fish farms in Turkey. For this purpose, some phenotypic properties of isolates were determined and then ELISA test was performed to determine serotypic differences. It was determined that all 22 L. garvieae isolates used in the study gave a cream colored, bright, rounded smooth S type colony in Triptic Soy Agar (TSA) and all strains were nonmobile in the native examination. Morphologically, all isolates were found to be Gram positive, nonmobile, $\alpha$-hemolytic, to have a growth of $0-6.5 \% \mathrm{NaCl}$ salinity, 21,37 and $45^{\circ} \mathrm{C}$ temperature, and to be oxidase and catalase negative. After examining the biochemical made with API Rapid ID 32 Strep test, it was observed that two L. garvieae isolates were different from the other isolates in terms of sucrose use and one L. garvieae isolate was different from other isolates in terms of maltose profile. According to the results of ELISA test used to determine the serotypical differences of the isolates, two L. garvieae isolates were serotypically different from the other isolates and L. garvieae isolates used in the study formed two different serotypic groups.
\end{abstract}

Keywords: Rainbow trout, L. garvieae, Serotype, ELISA

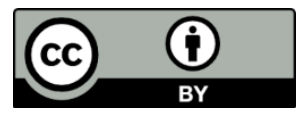

CCopyright 2020 by ScientificWebJournals Available online at 


\section{Introduction}

Rainbow trout, is the most cultured fish species in the world, because of its adaptability to environmental conditions, its ability to benefit from natural and artificial feed, and its resistance to diseases (Edwards, 1978).

Bacterial infections have an important place in fish diseases, and in the last decade Gram positive cocci have been identified as important fish pathogens. Many epidemic and sporadic diseases caused by Gram positive pathogens have been reported in various parts of the world (Arda et al., 2002). Japan, Singapore, Australia, Israel, Italy, Spain, France, South Africa and the United States are among the countries affected by outbreaks caused by Gram positive cocci (Eldar et al., 1999). Lactococcus garvieae, Yersinia ruckeri and Listonella anguillarum have been reported to be among the most common pathogens in rainbow trout (Çağırgan, 2009).

Lactococcosis is one of the most serious diseases that causes economic loss among the other diseases caused by Gram positive bacteria. Lactococcosis is a septicemic disease that causes economic loss in many fish species, especially rainbow trout, when the water temperature reaches $15^{\circ} \mathrm{C}$ in the summer months (Diler et al., 2002; Çağırgan, 2004; Balta and Balta, 2019).

In bacterial fish diseases, vaccination is one of the preventive measures. It is important to obtain and investigate different serotypes of the same bacterial species for vaccination studies. In this way, vaccines with high protection can be developed.

This study aimed to detect serological differences between $L$. garvieae strains identified as pathogens causing economic losses in our country.

\section{Material and Methods}

\section{Sampling}

240 rainbow trouts (Oncorhynchus mykiss) (20-300g) used in the study were taked from 30 active rainbow trout farms registered at the Ministry of Agriculture and Forestry in Van, Bitlis, Muş and Hakkari. While choosing the fish, pools were visited with the owner of the farm and care was taken to choose the fish that showed symptoms of disease. In the study, four different $L$. garvieae were isolated from the rainbow trout farms. 18 different $L$. garvieae isolates which were cultured were added to the study. The study was carried out with a total $22 \mathrm{~L}$. garvieae isolates.Sampling studies were carried out in June, July, August and September 2014. For the sampling, a 45-liter capacity container (Rubbermaid) was used.

\section{Phenotypic Determination of Isolates}

\section{Bacteria isolation}

Bacteriological samples from anterior kidney were streaked onto TSA. Petri plates were incubated at $21^{\circ} \mathrm{C}$ for 7 days in a cooled incubator. The colonies formed by the bacteria in the medium where reproduction was observed during the incubation period were examined in terms of morphological features such as color, shape and brightness (Austin and Austin, 1999). Gram staining of the growing bacteria (Beşe, 1993), Oxidase (Beşe, 1974) and Catalase (Aydın, 1992) tests were applied. For hemolysis test, 5\% sheep blood agar was streaked onto and classified according to zone areas (Buller, 2004).

\section{Salinity tolerance test}

To determine the physiological properties of the isolates, the tolerance of different salinity ratios was tested by the method of Konemann (1992). For this purpose, sterile TSA containing $4 \%$ and $6.5 \% \mathrm{NaCI}$ was prepared and inoculated petri plates were incubated at $21^{\circ} \mathrm{C}$ for 7 days. Isolates were evaluated as positive and non-growth isolates as negative.

\section{Temperature tolerance test}

The temperature tolerance tests of the isolates were applied according to Konemann (1992). The bacteria which had been planted in the TSA prepared sterile in order to determine the growth abilities at different temperatures were determined after 7 days incubation at 21,37 and $45^{\circ} \mathrm{C}$. Growth isolates were evaluated as positive and non-growth isolates as negative.

\section{Determination of serotypical differences}

ELISA test was used to determine the serotypic properties of L. garvieae isolates. ELISA test is carried out using two different methods, direct and indirect ELISA. Since the antigen are obtained from L. garvieae isolates and tested with the known antibody, indirect ELISA method was used in the study (Baraketi et al., 2020).

\section{Antigen production}

L. garvieae isolates growth in TSB were produced by incubating at Todd Hevith Broth (THB) for 24 hours at $25^{\circ} \mathrm{C}$. After adding 5\% formaldehyde (Sigma-F8775), it was inactivated by keeping it at $4{ }^{\circ} \mathrm{C}$ for 24 hours. It was centrifuged at $2500 \mathrm{rpm}$ for 15 minutes (Inovia-Ino 3H). After the bacterial precipitate obtained was washed three times with PBS, antigen density was prepared by adjusting it to $0.6 \pm 0.010$ optical density (OD) at $630 \mathrm{~nm}$ and used as antigen in ELISA test (Eyngor et al., 2004). 


\section{Immunization of rabbits}

The anti $L$. garvieae antibody used in the study was prepared for the rabbit by intravenous inoculation of $L$. garvieae isolate 12. L. garvieae isolates were used as antigens in the ELISA test. The antibody from adsorbed isolate 12 was used against other isolates. Adsorption was performed by the method reported by Eyngor et al. (2004).

\section{ELISA test}

U-based, 96-well polystyrene ELISA plates (Costar) were used for the ELISA test. All of the antigens obtained from $L$. garvieae isolates were coated with ELISA plates at a determined dilution rate and two parallel. The last two wells were used as negative controls.

The U-based ELISA plate was coated with PBS and with prepared antigen $50 \mu \mathrm{L}$ to each well with isolate 6 of L. garvieae standardized to $\mathrm{OD}_{630} 0.600 \pm 0.010$. The antigen-coated plate was left overnight at $4^{\circ} \mathrm{C}$. Two wells for each antigen were coated with antigen-free diluent. These wells were used as blank. To determine whether there was non-specific binding, control wells were created and the optimum concentration of reagents was determined by preliminary tests (Çağırgan, 2008).

Table 1. Antibody rates used in the study and format in ELISA plates

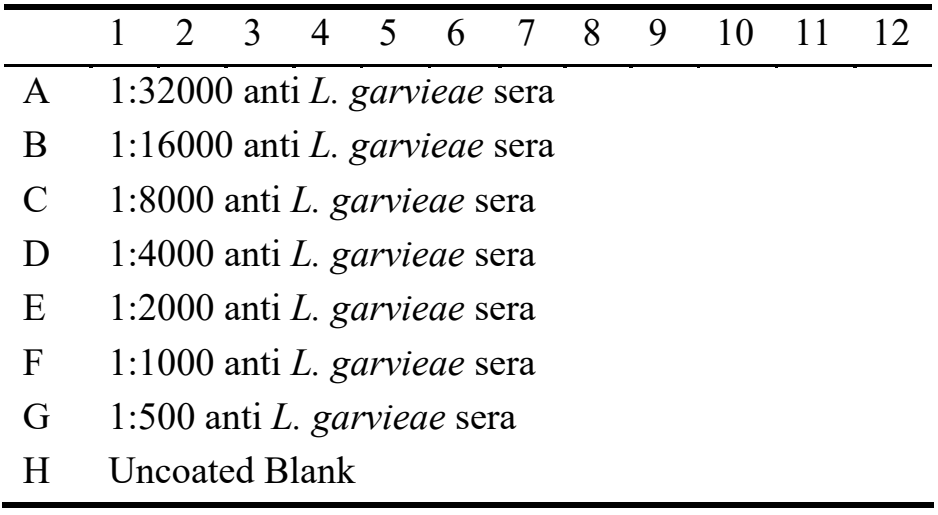

After washing the ELISA plate coated with antigen three times with PBS ( $\mathrm{pH} 7.4$ ), blocking was done and $100 \mu \mathrm{L}$ blocking solution (PBS $+1.5 \%$ Bovine Serum Albumin) was added to the wells to fill the empty areas in the wells. They were left in the water bath for 1 hour. 1\% BSA in 1:500, $1: 1000,1: 2000,1: 4000,1: 8000,1: 16000,1: 32000$ ratios for all eyes coated with antigen (Antigen density $\mathrm{OD}_{630}: 0,600$ ) after washing with PBS twice for two minutes serum was added, diluted with PBST (0.05\% Tween 20 added PBS), and the serum of adsorbed rabbit anti L. garvieae with antigen 12 was added. ELISA plates were incubated in a humidified sandwich box in an incubator at $37^{\circ} \mathrm{C}$ for one hour. To see the effect of adsorption of homologous serum with $L$. garvieae, the antigen-coated non-adsorbed anti $L$. garvieae serum was added to the eyes coated with antigen 12 in the same proportions as in the adsorbed serum. After all the wells were washed three times for two minutes with PBST, 1:20000\% $\mathrm{BSA}(1 \%)$ was added, and $50 \mu \mathrm{L}$ of goat anti-rabbit (KPL, 741506) conjugate labeled with PBST was placed and then the plates were incubated at $37^{\circ} \mathrm{C}$ for one hour. After incubation, the plate was washed four times with PBST for three minutes $100 \mu \mathrm{L}$ of TMB substrate (Sigma, T0440-100 mL) was added to all wells. After ten minutes of waiting at room temperature, the reaction was stopped by adding $50 \mu \mathrm{L}$ of $10 \%$ sulfuric acid to the wells (Voller et al., 1978). The results were read with an ELISA microplate reader (Versamax, Molecular Devices, USA) at a wavelength of $450 \mathrm{~nm}$.

\section{Evaluation of serotypical differences}

Standard deviation (STDDEVP) was calculated (Sümbü-

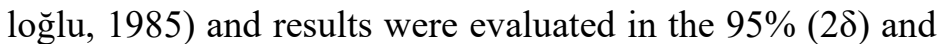
$98 \%(3 \delta)$ confidence intervals in order to reveal the differences in absorbance values of the blank value of $L$. garvieae isolates applied in the ELISA test.

\section{Results and Discussion}

\section{General Status of Farms}

The production capacities of the rainbow trout farms ranged from 1 to 500 tons. During the sample collection season, the air temperature ranged between $19^{\circ} \mathrm{C}$ and $38^{\circ} \mathrm{C}$, and the water temperature in the rainbow trout farms where sampling took place ranged from $13^{\circ} \mathrm{C}$ to $24^{\circ} \mathrm{C}$.

\section{Phenotypic Properties of L. garvieae Isolates}

Bacterial colonies obtained after incubation in TSA medium were found to be pin sized, round, bright in appearance, have sharp borders and to form S-type colonies. Then the colonies taken from TSA were incubated at TSB for 24 hours at $21^{\circ} \mathrm{C}$. TSA (Figure 1-A) and TSB (Figure 1-B) of L. garvieae isolates. After gram staining, it was observed that all of the isolates consisted of Gram positive cocci forming a short Lshaped chain painted with blue-purple color (Figure 1-C). The hemolysis properties of $L$. garvieae isolates obtained in TSA were examined in blood agar. After the 24-hour incubation period at $21^{\circ} \mathrm{C}$ in the blood agar, it was observed that all the isolates had $\alpha$-hemolytic properties and there was a light green area around the colonies that developed on the medium (Figure 1-D). 


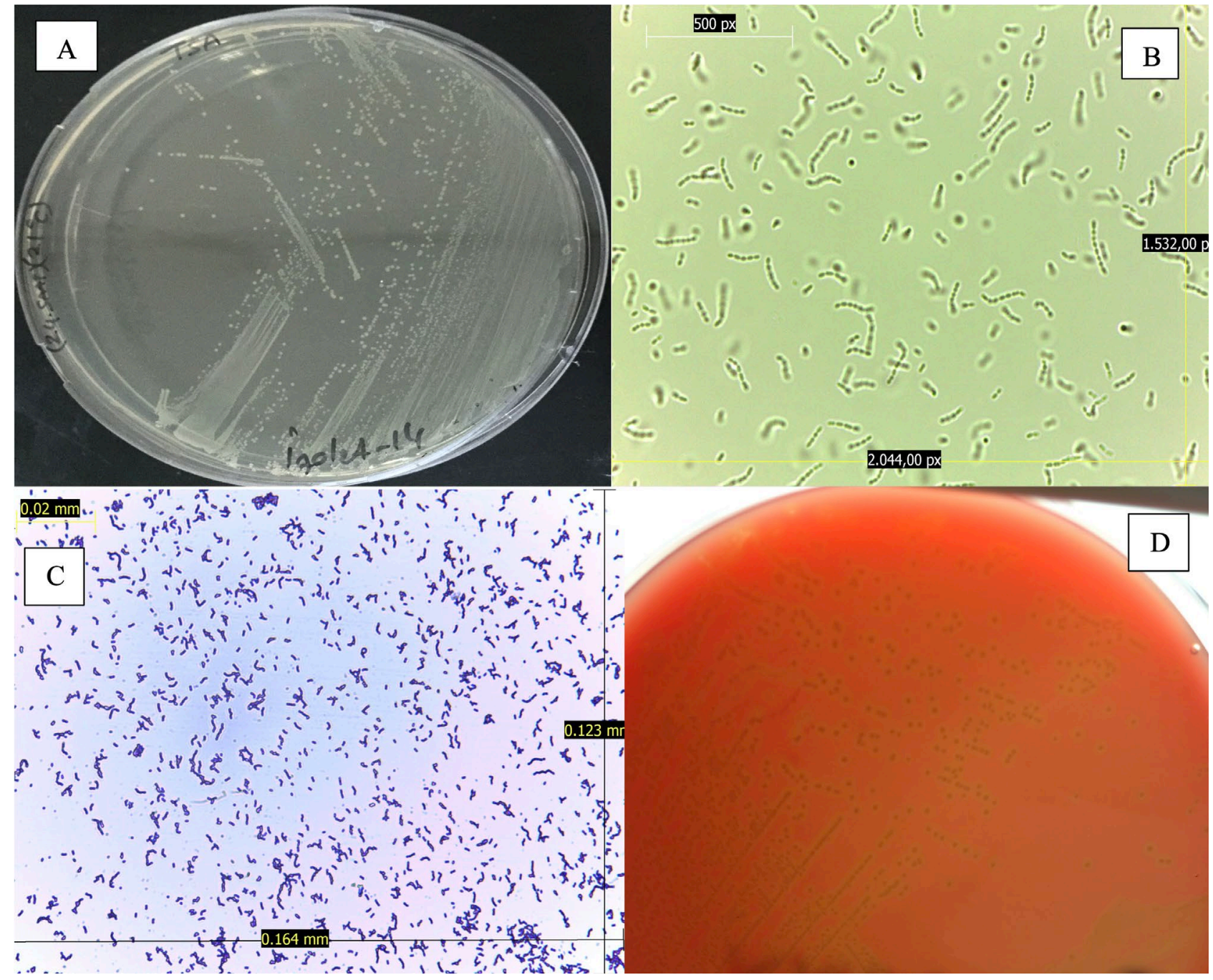

Figure 1. Phenotypic test results of $L$. garvieae isolates (A: TSA colony morphology, B: TSB bacteria type, C: Gram stain result, D: Hemolysis test result).

\section{Salinity Tolerance Test Results}

In determining the salinity tolerances of L. garvieae isolates, single colonies obtained from the isolates were added to TSA containing $4 \%$ and $6.5 \% \mathrm{NaCl}$. After the 7-day incubation period at $21^{\circ} \mathrm{C}$, all of the isolates showed growth in TSA prepared at $4 \%$ and $6.5 \%$ salinity $(\mathrm{NaCl})$ rates (Figure 2 ).

\section{Temperature Tolerance Test Results}

The isolates were incubated at temperature ranges of $21{ }^{\circ} \mathrm{C}$, $37^{\circ} \mathrm{C}$ and $45^{\circ} \mathrm{C}$. After the incubation period, all of the isolates were observed to grow at 21,37 and $45^{\circ} \mathrm{C}$. Therefore, it was understood that all the isolates used in the study were able to tolerate these temperature ranges (Figure 3 ).

\section{Evaluation of Serotypical Differences}

The differences between the isolates were evaluated according to the adsorbance data obtained after the ELISA test. While determining the serotypical differences between the isolates, standard deviation (STDDEVP) was calculated in order to reveal differences in absorbance values whose Blank value was decreased in ELISA test. The anti L. garvieae antibody used in the study was prepared by intravenous inoculation of L. garvieae strain no. 12 to the rabbit, and the agglutination titer of the serum obtained was 1:1024. 2 sigma value was deducted from the average of the adsorbance values and the results were evaluated in the excel program. The results were evaluated within the $95 \%(2 \delta)$ and $98 \%(3 \delta)$ confidence intervals. The graphic obtained according to the adsorbance values given by $L$. garvieae isolates after the ELISA test is given below (Figure 4). 


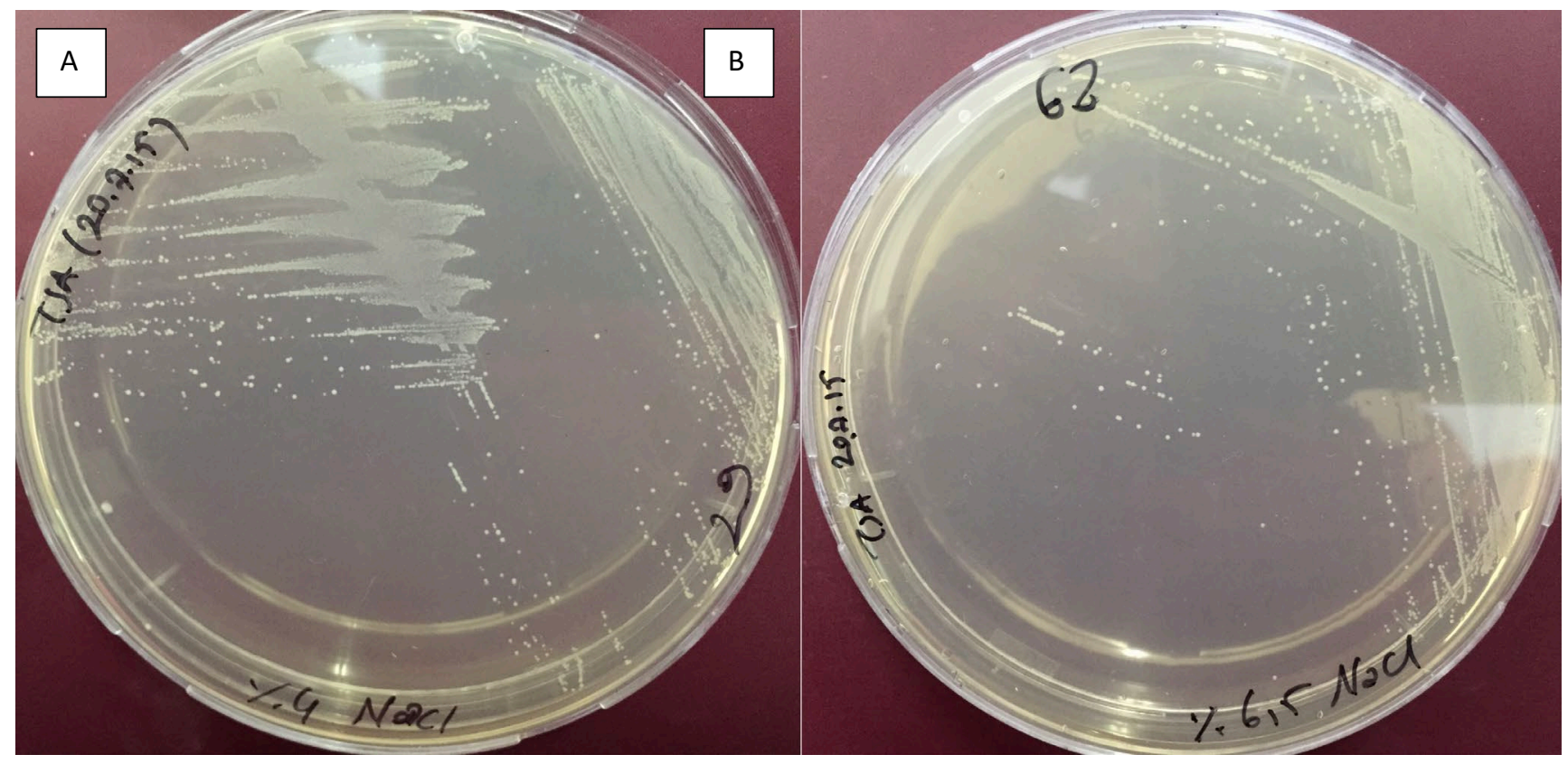

Figure 2. TSA medium image of L. garvieae isolates at 4\% (A) and 6.5\% (B) salinity

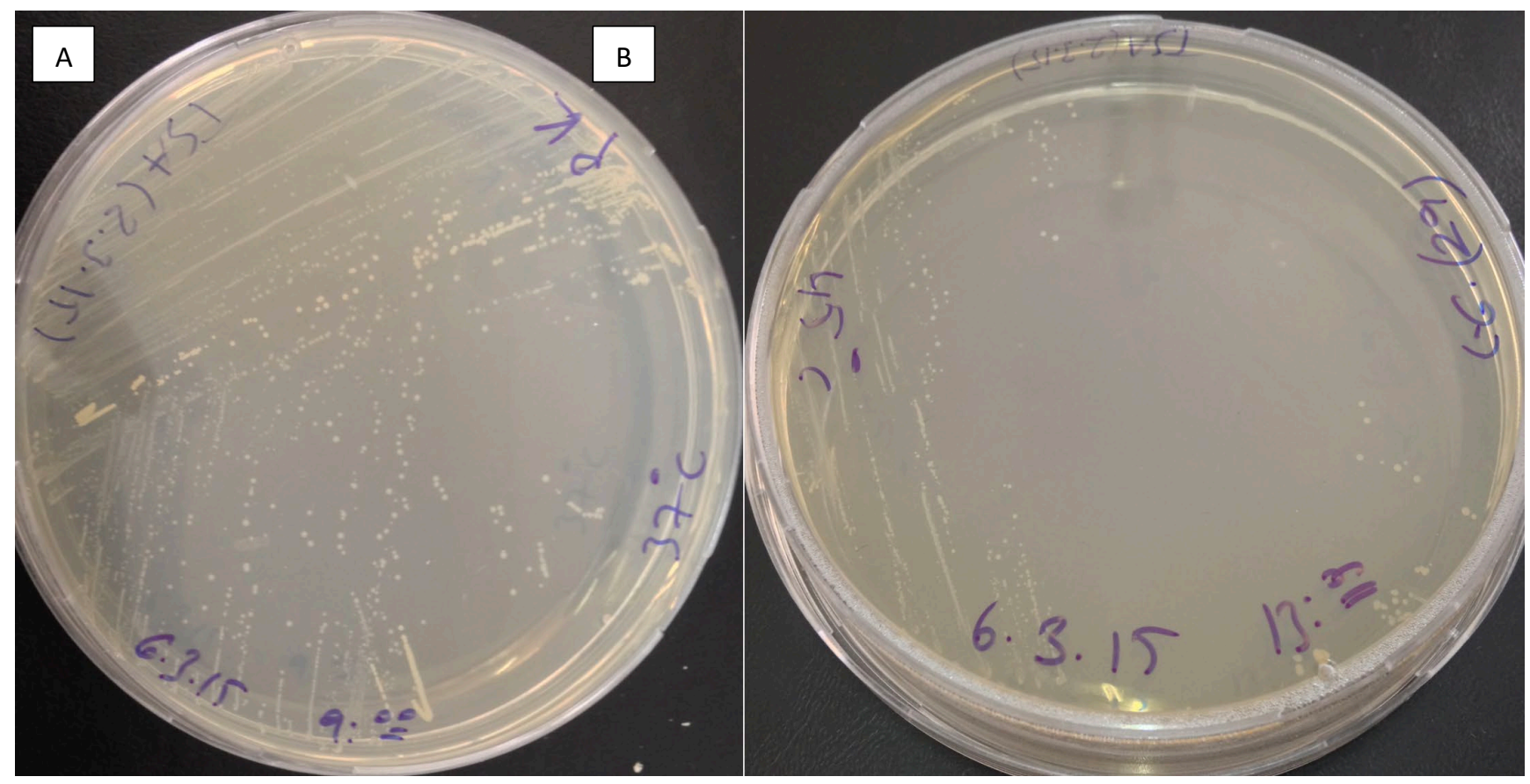

Figure 3. TSA medium image of L. garvieae isolates at $37^{\circ} \mathrm{C}(\mathrm{A})$ and $45^{\circ} \mathrm{C}(\mathrm{B})$ temparature. 


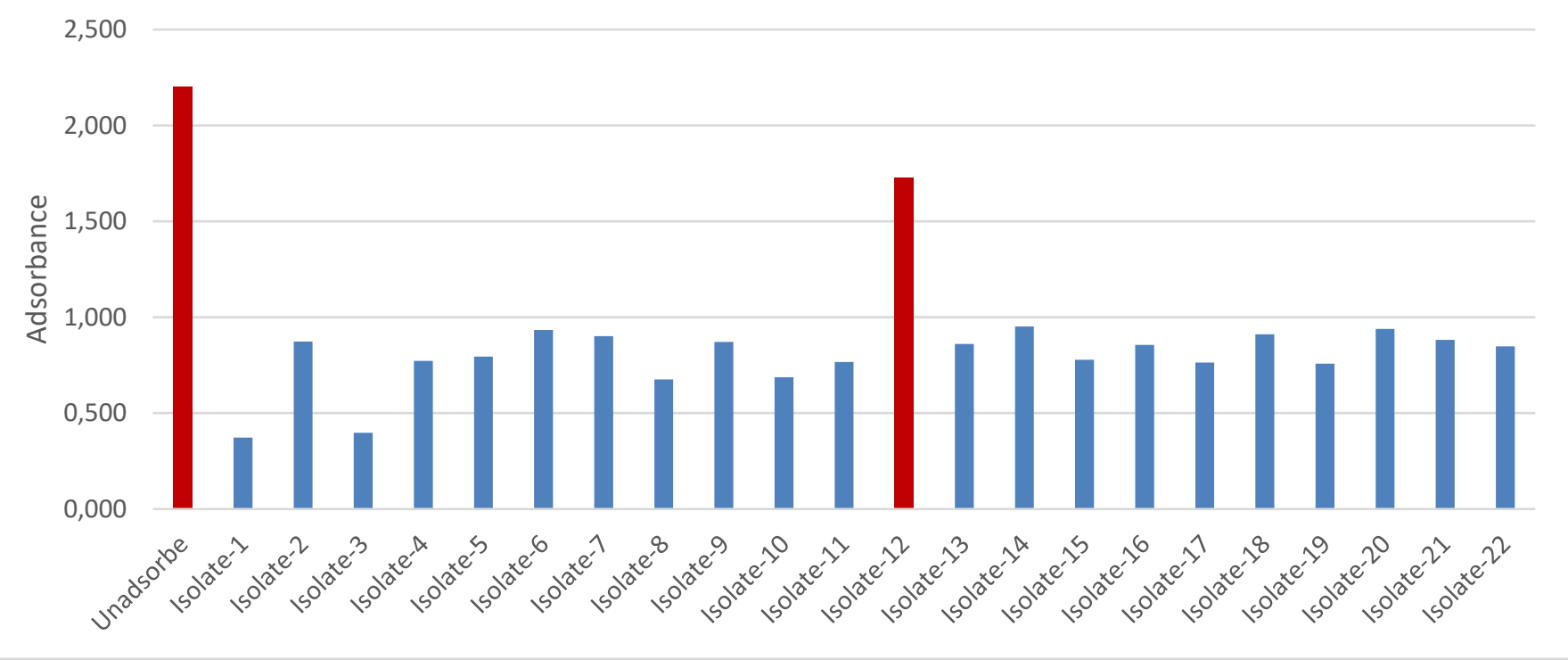

Figure 4. Groups obtained as a result of ELISA test of L. garvieae isolates.

According to the results obtained in the Excell program, an antibody prepared against isolate- 12 was used as serum and adsorbed with isolate-12. The values obtained when the average was deducted from 2 sigma $(0.49>)$ were evaluated as different serotypes in $95 \%$ confidence interval. According to Excel data; isolate- 1 and isolate-3 are grouped as serotype-1. Other L. garvieae isolates were evaluated as serotype-2 and L. garvieae isolates were divided into two different serotypical groups. The serotypic groups obtained after the ELISA test are given below (Table 2).

Table 2. Serotypic groups obtained from L. garvieae isolates after ELISA test.

\begin{tabular}{ll}
\hline Serotip & Isolate name \\
\hline Serotype 1 & Isolate 1 and Isolate 3 \\
Serotype 2 & Other 20 isolates \\
\hline
\end{tabular}

In this study, the sample collection was carried out in the summer, when the water temperature was highest because $14^{\circ} \mathrm{C}$ water temperature is a critical water temperature for lactococcosis. During sampling, it was observed that the air temperature ranged between $19^{\circ} \mathrm{C}$ and $38^{\circ} \mathrm{C}$, and the water temperature ranged between $13^{\circ} \mathrm{C}$ and $24^{\circ} \mathrm{C}$. Previous studies have reported that infection occurs when the water temperature in lactococcosis exceeds $14-15^{\circ} \mathrm{C}$ (Ghittino and Muzquiz, 1998; Soltani et al., 2008), and the mortality rate increases when the water temperature exceeds $18^{\circ} \mathrm{C}$ (Munday et al., 1993; Pereira et al., 2004). It has also been stated that the lactococcosis agent can be isolated from the endophthalmic fluid in the winter months (Savvidis et al., 2007).
Lactococcosis is a bacterial infection that shows specific symptoms in fish and causes large economic loss. Four typical symptoms of lactococcosis have been observed in rainbow trout farms where lactococcosis is seen and isolated. Standing and standing alone on the water surface are symptoms of acidity, bilateral exophthalmos and color darkening.

The immunological techniques used for serotyping studies are based on antigen-antibody interaction. In these methods, specific antibodies can be detected using a known antigen or specific antigens using a known antibody (Altınışık, 2004). The ELISA test is the most sensitive among the methods used in serological studies (Erkan et al., 2011; Ürkü and Timur, 2014).

The ELISA test was used to determine the serotypic characteristics and differences of $L$. garvieae strains used in this study. Previous researchers also used the ELISA method to determine the serotypic properties of $L$. garvieae strains (Voller, 1978; Pozo, 2005; Kav and Erganiş, 2008). Some researchers used the agglutination test for diagnostic purposes (Kitao, 1982; Knappskog et al., 1993). It has been reported that the agglutination test has a disadvantage in terms of cross-reactions and that the ELISA test is fast and economical (Bortz, 1984).

In the study, isolates 19, 20, 21 and 22 were isolated from Van, Bitlis, Muş and Hakkari provinces. The other isolates were previously cultured. Knowing the field data of $L$. garvieae strains $(19,20,21$ and 22) obtained from rainbow trout farms showed importance in terms of evaluating the re- 
sults obtained in the study. Mortality rates observed in rainbow trout farms where L. garvieae agents are isolated are as follows.

Table 3. Field data in rainbow trout farms with symptoms of lactococcosis.

\begin{tabular}{lcccc}
\hline & Water temperature & Mortality rate & Antibiotic & Vaccine \\
application & application \\
\hline Isolate-19 & $\left({ }^{\circ} \mathrm{C}\right)$ & $(\%)$ & - & - \\
Isolate-20 & $18-19$ & 5 & - & - \\
Isolate-21 & 21 & $<0,01$ & - & - \\
Isolate-22 & 18,5 & 2 & Enrofloxacin & - \\
\hline
\end{tabular}

When, Four L. garvieae strains (isolates 19, 20, 21 and 22) with known pathogenicity in the field were evaluated together with the field data obtained as a result of the study we obtained the following results: In the four isolates (isolates 19, 20, 21 and 22) that we obtained in the study, deaths started to occur when the water temperature exceeded $14^{\circ} \mathrm{C}$ in the farm where the isolate 22, which appeared the most pathogenic, was obtained and immediately after the treatment with Enrofloxacin (also compatible with antibiogram results). In the 8 days infection, $2 \%$ of the fish died.

In the farm where isolate 20 was obtained, although the fish were not vaccinated, deaths did not start above $14^{\circ} \mathrm{C}$ water temperature, but when the water temperature exceeded $21^{\circ} \mathrm{C}$, only 12 fish out of 500,000 fish were detected and lactococcosis were observed. Rainbow trout farms where isolates 19 and 21 are obtained are located in geographical regions close to each other. It was observed that the water temperature ranged between $18-19^{\circ} \mathrm{C}$ in both farms. According to the field data of these two rainbow trout farms, lactococcosis was observed to have different mortality rates in both farms where antibiotics and vaccines were not administered. According to field data, the different mortality rates in farms from which isolates 19 and 21 are obtained coincide with the data we obtained in the study.

\section{Conclusions}

In summary, according to the results of this study, L. garvieae strains 19 and 21 were evaluated as two different types of $L$. garvieae strains due to phenotypic and serotypic differences. While the field data is not known, Turkey isolated from various strains of 18 L. garvieae at different times. Therefore, the phenotypic and serotypic differences obtained in this study could not be evaluated together with the field data of these strains.

As a result of the study, it was found that isolating the differences in terms of pathogenicity in the same environmental conditions was important in terms of evaluating the data together. When the results of this study are evaluated together, these results are considered to be important in terms of preventing the damages caused by lactococcosis. The repetition and improvement of the methods used could also be an important step for future studies.

\section{Compliance with Ethical Standard}

Conflict of interests: The authors declare that for this article they have no actual, potential or perceived conflict of interests.

Ethics committee approval: This study was carried out with the permission document obtained by Van Yuzuncu Yil University, Animal Experts Local Ethics Committee dated 18/11/2013 and numbered 341.

Funding disclosure: This work; It covers a part of the $\mathrm{PhD}$ thesis study supported by Van YYU Scientific Research Projects Coordination Unit (BAP) numbered 2014-FBE-D025.

Acknowledgments: -

\section{References}

Ağaçfidan, A., Anğ, Ö., Badur, S., Bozkaya, E., Dernetli, Ş., Küçüker, M., Gürler, B., Öner, Y.A., Öngen, B., Töreci, K., Yeğenoğlu, Y. (2002). Medical Microbiology, Istanbul University Microbiology and Clinical Microbiology Department, Antigen-Antibody Reactions and Indirect Diagnostic Methods, (Ed: Bozkaya, E.) Nobel Medical Bookstore, ISBN: 975-420-230-3.

\begin{abstract}
Altınışık, M. (2004). Immunological Techniques. ADÜTF Biyokimya A.D., $2004 . \quad$ http://www.mustafaaltinisik.org.uk/45-uzm-03.pdf (Access date: 19.04.2013).
\end{abstract}

Arda, M., Seçer, S., Sarıeyyüpoglu, M. (2002). Fish Diseases. Medisan Publishing Series, 1st Edition, Ankara. ISBN 975-7774-58-8 
Austin, B., Austin, D.A. (2007). Bacterial Fish Pathogens Disease of Farmed and Wild Fish, Fourth Edition, Springer Dordrecht Berlin Heidelberg New York, ISBN 978-1-40206068-7.

Austin, B., Austin, D.A. (1999). Bacterial fish pathogens: Disease in Farmed and Wild Fish. 3rd (Revised) Edition. Praxis Publishing, Chichester, UK. ISBN: 978-1-4020-60694

Aydın, N. (1992). Identification of Gram positive, catalase negative cocci isolated from clinical samples. Erciyes University, Faculty of Medicine, Department of Microbiology, (Doctoral dissertation). Health Sciences Institute, 1992.

Balta, F., Dengiz Balta, Z. (2019). The isolation of Lactococcus garvieae from eyes of diseased rainbow trout (Oncorhynchus mykiss) with exopthalmia. Anatolian Environmental and Animal Sciences, 4(1), 27-33.

https://doi.org/10.35229/jaes.527258

Baraketi, A., D'Auria, S., Shankar, S., Fraschini, C., Salmieri, S., Menissier, J., Lacroix, M. (2020). Novel spider web trap approach based on chitosan/cellulose nanocrystals/glycerol membrane for the detection of Escherichia coli O157: H7 on food surfaces. International journal of biological macromolecules, 146, 1009-1014.

https://doi.org/10.1016/j.ijbiomac.2019.09.225

Barnes, A.C., Ellis, A.E. (2004). Role of Capsule in Serotypic Differences and Complement Fixation by L. garvieae. Fish and Shellfish Immunology, 16, 207-214.

https://doi.org/10.1016/S1050-4648(03)00079-2

Beşe, M. (1974). Biochemical Tests and Media Used in Microbiology. Ankara University, Faculty of Veterinary Medicine Publications, 298, p: 96-162, Ankara.

Beşe, M. (1993). Stains and Dyeing Methods Used in Microbiology. Istanbul University, Faculty of Veterinary Medicine Publications, p: 47-50.

Bortz, B. M. (1984). The immune response in immunized and naturally infected rainbow trout (Salmo gaidneri) Diplostomum spataceum as detected by Enzyme- Linked immunosorbent assay (ELISA), Developmental \& Comparative Immunology, 8, 813-822.

https://doi.org/10.1016/0145-305X(84)90064-8
Buller, N.B. (2004). Bacteria from fish and other aquatic animals. In: Buller, N.B. Bacteriological culture techniques:microscopy, culture and identification, (p.83-90). CABI Publishing. ISBN 9780851997384.

https://doi.org/10.1079/9780851997384.0000

Çağırgan, H. (2004). Biotyping of $L$. garvieae Isolated from Turkey. Ege Üniversitesi Su Ürünleri Dergisi, Journal of Fisheries \& Aquatic Sciences, 21 (3), 267-269.

Çağırgan, H. (2008). Development of Enzyme Linked Immunosorbent Assay for Diagnosis of Infectious Pancreatic Necrosis Disease. The Journal of Bornova Veterinary Science, 30 (44), 15-22.

Çağırgan, H. (2009). The use of veterinary drugs and vaccines in Turkey. Zaragoza: CIHEAM, 2009. p.29 -34.

https://doi.org/10.1111/j.1753-4887.1971.tb07230.x

Diler, O., Altun, S., Adiloğlu, A., Kubilay, A., Işıklı, B. (2002). First Occurance of Streptococcosis Affecting Farmed Rainbow Trout in Turkey. Bulletin of the European Association of Fish Pathologist, 22 (1), 21-26.

Edwards, D.J. (1978). Salmon and Trout Farming in Norway. Farnham, England. Fishing News Books Ltd. ISBN: 10:0852380933

Eldar, A., Goria, M., Ghittino, C., Zlotkin, A., Bercovier, H. (1999). Biodiversity of L. garvieae Strains Isolated from Fish in Europe, Asia, and Australia. Applied and Environmantal Microbiology. 65(3), 1005-1008.

https://doi.org/10.1128/AEM.65.3.1005-1008.1999

Erkan, S., Gümüş, M., Paylan, İ.C., Sipahioğlu, H.M. (2011). Serological Methods Used to Identify Plant Viruses. Electronic Journal of Microbiology, 9(2), 35-49.

Eyngor, M., Zlotkin, A., Ghittino, C., Prearo, M., Douet, D.G., Chilmonczyk, S., Eldar, A. (2004). Clonality and diversity of the fish pathogen $L$. garvieae in Mediterranean countries. Applied and Environmantal Microbiology, 70, 5132-5137.

https://doi.org/10.1128/AEM.70.9.5132-5137.2004

Ghittino, C., Muzquiz, J.L. (1998). Streptococcosis of rainbow trout in Spain. Fish Farmers Meeting. Zaragoza Reviews Aquatica, 2(2), 1-7.

Kav, K., Erganis, O. (2008). Immune System in Fish. Vet. Know. Bull., 24(1), 97-106. 
Kitao, T. (1982). The Methods for Detection of Streptococcus sp. Causative Bacteria of Streptococcal Disease of Cultured Yellowtail (Seriola quinqueradiata). Fish Pathology, $17,17-26$.

https://doi.org/10.3147/jsfp.17.17

Knappskog, D.H., Rodseth, O.M., Slinde, E., Endresen, C. (1993). Immunochemical analyses of Vibrio anguillarum strains isolated from cod, Gadus morhua L., suffering from vibriosis. Journal of Fish Diseases, 16, 327-338.

https://doi.org/10.1111/j.1365-2761.1993.tb00866.x

Konemann, E.W. (1992). Color Atlas and Diagnostic Microbiology. ISBN 0-1234455-3, 258-125.

Munday, B.L., Jack, D.L., Schmidtke, L. (1993). Pathogenicity of the species Streptococcus causing disease in rainbow trout (Onchorynchus mykiss). Bulletin of the European Association of Fish Pathologists, 13(1), 25-27.

Pereira, F., Ravelo, C., Toranzo, A.E., Romalde, J.L. (2004). L. garvieae, an emerging pathogen for the Portuguese trout culture. Bulletin of the European Association of Fish Pathologists, 24(8), 274-279.

Pozo, J.D. (2005). Studies on Monoclonal Antibodies Characterization and Immuno histochemical Detection of $L$. garvieae. Institute of Aquaculture, University of Stirling, Scotland.

Sauer, M.J., Foulkes, J.A., Morris, B.A. (1985). Principles of Enzyme Immunoassay. 53-72. In: Morris, B.A., Clifford, M.N. (Eds): Immunoassays in Food Analysis. Elsevier Applied Science Publishers, London.
Savvidis, G.K., Anatolıtis, C., Kanaki, Z., Vafeas, G. (2007). Epizootic outbreak of laktokokkozis disease in rainbow trout culture in Greece. Bulletin of the European Association of Fish Pathologists, 27(6), 223.

Soltani, M., Nikbakht, G.H., Mousavi, H.A.E., Ahmadzadeh, N. (2008). Epizootic outbreaks of laktokokkozis caused by L. garvieae in farmed rainbow trout (Oncorhynchus mykiss) in Iran. Bulletin of the European Association of Fish Pathologists, 28 (5): 170-175.

Sümbüloğlu, K. (1985). Special Statistical Methods in the Field of Health. TTB Ankara Chamber of Medicine Publication, (4), 283.

Us, D. (2006). Serological Diagnosis Methods Application and Evaluation. Hacettepe University publications, 975491208-4.

Ürkü, Ç., Timur, G. (2014). A comparative study of detection methods for Lactococcus garvieae in experimentally infected rainbow trout (Oncorhynchus mykiss, W.). The Israeli Journal of Aquaculture-Bamidgeh.

Voller, A., Bartlett, A., Bidwell, D.E. (1978). Enzyme immunoassays with special reference to ELISA techniques. Journal of Clinical Pathology, 31, 507- 520.

https://doi.org/10.1136/jcp.31.6.507 